\title{
Commentary: The apolipoprotein A-I mimetic peptide, D-4F, restrains neointimal formation through heme oxygenase-1 up-regulation
}

\author{
Giovanni Li Volti*, Roberto Avola and Daniele Tibullo \\ Department of Biomedical and Biotechnological Sciences, University of Catania, Catania, Italy
}

Keywords: endothelium, vascular, smooth muscle cells, neointima formation, restenosis, vascular diseases

\section{OPEN ACCESS}

Edited by:

Kostas Pantopoulos,

McGill University, Canada

Reviewed by:

Abolfazl Zarjou,

University of Alabama at Birmingham,

United States

Ana Claudia Zenclussen,

Otto-von-Guericke-Universität

Magdeburg, Germany

Alain Le Moine,

Free University of Brussels, Belgium

*Correspondence:

Giovanni Li Volti

livolti@unict.it

Specialty section:

This article was submitted to

Experimental Pharmacology and Drug

Discovery,

a section of the journal

Frontiers in Pharmacology

Received: 22 August 2017 Accepted: 21 September 2017

Published: 29 September 2017

Citation:

Li Volti G, Avola R and Tibullo D (2017) Commentary: The apolipoprotein A-I

mimetic peptide, $D-4 F$, restrains neointimal formation through heme

oxygenase- 1 up-regulation.

Front. Pharmacol. 8:708.

doi: 10.3389/fphar.2017.00708

\section{A commentary on}

The apolipoprotein A-I mimetic peptide, D-4F, restrains neointimal formation through heme oxygenase- 1 up-regulation

by Liu, D., Wu, M., Du, Q., Ding, Z., Qian, M., Tong, Z., et al. (2017). J. Cell. Mol. Med. doi: 10.1111/ jcmm. 13290

We read with great interest the work of Liu et al. (2017b) showing that D-4F inhibited vascular smooth muscle cells (VSMC) proliferation and migration in vitro and neointimal formation in vivo through heme oxygenase-1(HO-1) up-regulation. Authors' conclusions further demonstrate that HO- 1 represents a druggable target for vascular injury prevention and that D-4F may be exploited as a safe and effective treatment to induce HO-1 into a clinical setting. In fact, previous reports showed that a single dose of $\mathrm{D}-4 \mathrm{~F}$ is safe and well tolerated in patients with coronary heart disease (Bloedon et al., 2008; Sherman et al., 2010). Furthermore, D-4F, besides being an inducer of HO-1, exhibited pleiotropic effects contributing to vascular homeostasis such as antioxidant and antiinflammatory effects (Kruger et al., 2005; Rosenbaum et al., 2015; Liu et al., 2017a). Interestingly, all these effects are consistent with $\mathrm{HO}-1$ biological functions. In particular, HO-1 may be expressed under basal conditions (Maines et al., 1986; Bauer et al., 1998) and it is induced by different compounds and stress-related stimuli (Li Volti et al., 2008; Bramanti et al., 2012; Barbagallo et al., 2013). In addition, a number of natural antioxidant compounds contained in foods and plants have been demonstrated to be effective non-stressful and non-cytotoxic inducers of the response protein HO-1 in various cellular models. Most of these compounds are contained in plants, which besides having been widely used as food, spices, or flavoring also represent locally traditional medicinal plants. However, such compounds have intrinsic antioxidant and anti-inflammatory effects because of their ability to induce antioxidant responsive elements (ARE) which are responsible for cellular homeostasis maintenance; on the other hand, D-4F has specific activity on HO-1 induction. Finally, one more aspects deserves to be pointed out referring to the interesting work of Liu et al. Noteworthy, the biological effects of HO-1 have been shown to be cell specific. In fact, several lines of evidence are consistent with the authors' conclusion regarding the effect of HO-1 on VSMC proliferation and migration in vitro (Li Volti et al., 2002; Durante, 2010). On the other hand, HO1 induction results in a significant increase of endothelial cell proliferation (Li Volti et al., 2002, 2005). Such particular cell specificity is of great clinical interest in the case of vascular injury and neointima formation since this process is characterized by increased VSMC proliferation with a reduction of endothelial formation. To this regard, Duckers et al. (2001) showed that HO-1 reduced the proliferative response to vascular injury in vivo and reduced VSMC proliferation in vivo via p21 
regulation. Taken all together, the work of Liu et al. provide a significant pharmacological tool to exploit HO-1 beneficial effects into a clinical setting with particular regard to restenosis.

\section{REFERENCES}

Barbagallo, I., Galvano, F., Frigiola, A., Cappello, F., Riccioni, G., Murabito, P., et al. (2013). Potential therapeutic effects of natural heme oxygenase1 inducers in cardiovascular diseases. Antioxid. Redox Signal. 18, 507-521. doi: 10.1089 /ars.2011.4360

Bauer, I., Wanner, G. A., Rensing, H., Alte, C., Miescher, E. A., Wolf, B., et al. (1998). Expression pattern of heme oxygenase isoenzymes 1 and 2 in normal and stress-exposed rat liver. Hepatology 27, 829-838. doi: 10.1002/hep.510270327

Bloedon, L. T., Dunbar, R., Duffy, D., Pinell-Salles, P., Norris, R., DeGroot, B. J., et al. (2008). Safety, pharmacokinetics, and pharmacodynamics of oral apoAI mimetic peptide D-4F in high-risk cardiovascular patients. J. Lipid Res. 49, 1344-1352. doi: 10.1194/jlr.P800003-JLR200

Bramanti, V., Tomassoni, D., Grasso, S., Bronzi, D., Napoli, M., Campisi, A., et al. (2012). Cholinergic precursors modulate the expression of heme oxigenase1 , p21 during astroglial cell proliferation and differentiation in culture. Neurochem. Res. 37, 2795-2804. doi: 10.1007/s11064-012-0873-3

Duckers, H. J., Boehm, M., True, A. L., Yet, S. F., San, H., Park, J. L., et al. (2001). Heme oxygenase-1 protects against vascular constriction and proliferation. Nat. Med. 7, 693-698. doi: 10.1038/89068

Durante, W. (2010). Targeting heme oxygenase-1 in vascular disease. Curr. Drug Targets 11, 1504-1516. doi: 10.2174/1389450111009011504

Kruger, A. L., Peterson, S., Turkseven, S., Kaminski, P. M., Zhang, F. F., Quan, S., et al. (2005). D-4F induces heme oxygenase-1 and extracellular superoxide dismutase, decreases endothelial cell sloughing, and improves vascular reactivity in rat model of diabetes. Circulation 111, 3126-3134. doi: 10.1161/CIRCULATIONAHA.104.517102

Liu, D., Ding, Z., Wu, M., Xu, W., Qian, M., Du, Q., et al. (2017a). The apolipoprotein A-I mimetic peptide, D-4F, alleviates ox-LDL-induced oxidative stress and promotes endothelial repair through the eNOS/HO-1 pathway. J. Mol. Cell. Cardiol. 105, 77-88. doi: 10.1016/j.yjmcc.2017.01.017

Liu, D., Wu, M., Du, Q., Ding, Z., Qian, M., Tong, Z., et al. (2017b). The apolipoprotein A-I mimetic peptide, D-4F, restrains neointimal

\section{AUTHOR CONTRIBUTIONS}

GL, RA, and DT reviewed scientific literature and contributed to the writing of this article.

formation through heme oxygenase-1 up-regulation. J. Cell. Mol. Med. doi: $10.1111 /$ jcmm.13290. [Epub ahead of print].

Li Volti, G., Sacerdoti, D., Di Giacomo, C., Barcellona, M. L., Scacco, A., Murabito, P., et al. (2008). Natural heme oxygenase-1 inducers in hepatobiliary function. World J. Gastroenterol. 14, 6122-6132. doi: 10.3748/wjg.14.6122

Li Volti, G., Sacerdoti, D., Sangras, B., Vanella, A., Mezentsev, A., Scapagnini, G., et al. (2005). Carbon monoxide signaling in promoting angiogenesis in human microvessel endothelial cells. Antioxid. Redox Signal. 7, 704-710. doi: 10.1089/ars.2005.7.704

Li Volti, G., Wang, J., Traganos, F., Kappas, A., and Abraham, N. G. (2002). Differential effect of heme oxygenase-1 in endothelial and smooth muscle cell cycle progression. Biochem. Biophys. Res. Commun. 296, 1077-1082. doi: 10.1016/S0006-291X(02)02054-5

Maines, M. D., Trakshel, G. M., and Kutty, R. K. (1986). Characterization of two constitutive forms of rat liver microsomal heme oxygenase. Only one molecular species of the enzyme is inducible. J. Biol. Chem. 261, 411-419.

Rosenbaum, M. A., Chaudhuri, P., Abelson, B., Cross, B. N., and Graham, L. M. (2015). Apolipoprotein A-I mimetic peptide reverses impaired arterial healing after injury by reducing oxidative stress. Atherosclerosis 241, 709-715. doi: 10.1016/j.atherosclerosis.2015.06.018

Sherman, C. B., Peterson, S. J., and Frishman, W. H. (2010). Apolipoprotein A-I mimetic peptides: a potential new therapy for the prevention of atherosclerosis. Cardiol. Rev. 18, 141-147. doi: 10.1097/CRD.0b013e3181c4b508

Conflict of Interest Statement: The authors declare that the research was conducted in the absence of any commercial or financial relationships that could be construed as a potential conflict of interest.

Copyright (c) 2017 Li Volti, Avola and Tibullo. This is an open-access article distributed under the terms of the Creative Commons Attribution License (CC BY). The use, distribution or reproduction in other forums is permitted, provided the original author(s) or licensor are credited and that the original publication in this journal is cited, in accordance with accepted academic practice. No use, distribution or reproduction is permitted which does not comply with these terms. 